\title{
Development of a Single-Step Subtraction Method for Eukaryotic 18S and 28S Ribonucleic Acids
}

\author{
Marie J. Archer and Baochuan Lin \\ Center for Bio/Molecular Science and Engineering, Naval Research Laboratory, Washington, DC 20375, USA \\ Correspondence should be addressed to Marie J. Archer, marie.j.archer@gmail.com
}

Received 21 February 2011; Accepted 29 April 2011

Academic Editor: Tanya Parish

Copyright (๑) 2011 M. J. Archer and B. Lin. This is an open access article distributed under the Creative Commons Attribution License, which permits unrestricted use, distribution, and reproduction in any medium, provided the original work is properly cited.

\begin{abstract}
The abundance of mammalian $18 \mathrm{~S}$ and $28 \mathrm{~S}$ ribosomal RNA can decrease the detection sensitivity of bacterial or viral targets in complex host-pathogen mixtures. A method to capture human RNA in a single step was developed and characterized to address this issue. For this purpose, capture probes were covalently attached to magnetic microbeads using a dendrimer linker and the solid phase was tested using rat thymus RNA (mammalian components) with Escherichia coli RNA (bacterial target) as a model system. Our results indicated that random capture probes demonstrated better performance than specific ones presumably by increasing the number of possible binding sites, and the use of a tetrame-thylammonium-chloride (TMA-Cl-) based buffer for the hybridization showed a beneficial effect in the selectivity. The subtraction efficiency determined through real-time RT-PCR revealed capture-efficiencies comparable with commercially available enrichment kits. The performance of the solid phase can be further fine tuned by modifying the annealing time and temperature.
\end{abstract}

\section{Introduction}

The detection and analysis of low-abundance nucleic acids (NAs) in complex host-pathogen mixtures requires the enrichment of the target of interest prior to any downstream process which means eliminating host material, nucleases, and PCR inhibitors [1,2]. Magnetic-bead-based isolation methods using specific capture probes are well established, and they have been demonstrated to be versatile and efficient [2]. In any application which relies on the analysis of ribonucleic acids (RNAs), such as viral identification or genomic profiling, the selective separation of the RNA targets of interest also has to ensure the integrity of the templates in order to obtain meaningful results [3]. Chloroform-based extraction methods have been traditionally used for this purpose with satisfactory results; however, the laborious steps involved, the possible loss of template, and the use of toxic reagents have diminished the enthusiasm in their use $[4,5]$.

Single-step methods for RNA capture emerged more than a decade ago in response to a need to reduce the use of the phenol-based extraction. Direct capture of RNA was attempted using solid phases with capture probes linked through affinity (biotin-streptavidin) [5-7] or short covalent bonds [8-11]. However, the low capture efficiency and the inconsistency of the results along with problems of nonspecific adsorption led to the development of the currently used two-step method. In this method, a capture probe is hybridized in solution with the target of interest and the probe-target complex is then captured on magnetic beads [12-18]. While the biotin-streptavidin system is the most widely used approach, there are other commercially available products that utilize short oligonucleotides as capture moieties [19-25].

The presence of ribosomal RNA (rRNA) in clinical samples is one of the major interferers for downstream analysis. In some circumstances, when the interfering RNA is not removed, the amount of total RNA used has to be increased significantly $(>50 \mu \mathrm{g})$ in order to obtain the desired sensitivity [26]. Other approaches [27-29] for enrichment of bacterial RNA by selective or differential hybridization of the human components have been reported; however, they are complex and cumbersome, requiring numerous steps and sometimes length hybridization time. Moreover, 
separate selective capture of the rRNA and the targets using biotinylated probes and streptavidin-conjugated beads is usually necessary. These methods make the currently known approaches expensive and prone to contamination and loss of template [27-29].

For diagnostic applications, there is an increasing interest in developing methods to remove eukaryotic rRNA ( $18 \mathrm{~S}$ and 28S) from bacterial targets since it has been observed that the former can compete with the targets of interest during cDNA synthesis and labeling [21]. Methods to specifically remove $18 \mathrm{~S}$ and $28 \mathrm{~S}$ RNA are commercially available (that is, MICROBEnrich kit, Ambion, Austin, Tex, USA), and they have been used for enrichment of bacterial RNA in various clinical applications $[21,24,25]$. For this method, the sample containing bacterial and mammalian RNA is first hybridized with a mixture of capture oligonucleotides in solution and then with magnetic beads derivatized with an oligonucleotide complementary to the free tail of the capture oligo. Even though the routinely used two-step method has been demonstrated to be suitable for many applications, it is always desirable to minimize the number of manual steps in order to prevent loss of target and/or potential contamination.

In the work presented here, we describe a method for single-step capture of mammalian rRNA (18S and 28S) using a branched phosphorus dendrimer as linker on the solid phase. Previous reports have shown the dendrimer linker provides a tunable loading capacity and a long linker length which is known to positively influence the capture efficiency [8-10]. Moreover, this linker forms very stable covalent bonds which ensure the probe remains bound to the surface hence eliminating the possibility of probe shedding [30]. Based on these findings, we evaluated the capture efficiency as a function of the probe density and compared the performance of the solid-phase system developed here with the commercially available equivalent method.

\section{Materials and Methods}

2.1. Materials. Aminofunctionalized magnetic microbeads were purchased from Chemiell GmbH (Berlin,Germany). Thiophosphoryl dendrimers generation 5.5 was purchased from Sigma-Aldrich (St. Louis, Mo, USA) and used as received. Rat thymus RNA, Escherichia coli RNA, and MICROBEnrich kit were purchased from Ambion (Austin, Tex, USA) and used according to the manufacturer's instructions. All the primers used for the capture probe synthesis had an AminoC6 modification and were purchased from the Operon Biotechnology (Huntsville, Ala, USA). Random hexamers, DNA Polymerase I, and SuperScript II were obtained from Invitrogen Life Technologies (Carlsbad, Calif, USA). Klenow fragment $\left(3^{\prime} \rightarrow 5^{\prime}\right.$ exo $\left.^{-}\right)$was purchased from New England Biolabs (Ipswich, Mass, USA). GoTaq Flexi Polymerase was obtained from Promega Corporation (Madison, Wis, USA). All solutions were prepared with nuclease free water.

2.2. Specific $18 S$ and $28 S$ Capture Probe Synthesis. Specific capture probes for $18 \mathrm{~S}$ or $28 \mathrm{~S}$ were synthesized by PCR using
T3 (amino labeled) and $18 \mathrm{~S}$ or $28 \mathrm{~S}$ reverse primers (listed in Table 1) with pTRI RNA $18 \mathrm{~S}$ or $28 \mathrm{~S}$ control templates (Ambion). PCR reactions were performed in $50 \mu \mathrm{L}$ volumes containing 1x colorless GoTaq Flexi Buffer, $3 \mathrm{mM} \mathrm{MgCl}_{2}$, $400 \mu \mathrm{M}$ each of dATP, dCTP, dGTP, and dUTP, $3 \mu \mathrm{M}$ of primer $\mathrm{T} 3$ and $300 \mathrm{nM}$ of $18 \mathrm{~S}$ or $28 \mathrm{~S}$ reverse primers, $3 \mathrm{U}$ of GoTaq DNA polymerase (Promega), and $1 \mu \mathrm{L}$ of template $(1 \mathrm{ng} / \mu \mathrm{L})$. The amplification reaction was carried out in Peltier Thermal Cycler-PTC240 DNA Engine Tetrad 2 (Bio-Rad Laboratories Inc., Hercules, Calif, USA) with preliminary denaturation at $94^{\circ} \mathrm{C}$ for $2 \mathrm{~min}$., followed by 40 cycles of $94^{\circ} \mathrm{C}$ for $30 \mathrm{sec}$., $54^{\circ} \mathrm{C}$ for $30 \mathrm{sec}$., and $72^{\circ} \mathrm{C}$ for $30 \mathrm{sec}$.

2.3. Random Capture Probe Synthesis. Random capture probes were synthesized using rat thymus RNA as template. The rat thymus RNA was reverse transcribed to doublestranded cDNA using random hexamer and SuperScript II (Invitrogen Life Technologies) according to manufacturer's recommended protocol. The cDNA products were purified with QIAquick PCR purification kit (Qiagen Inc., Valencia, Calif, USA) following the manufacturer's recommendation, and used for Klenow probe synthesis as described in previous report [31]. Briefly, the Klenow probes were prepared in a $50 \mu \mathrm{L}$ reaction volume containing $10 \mathrm{mM}$ Tris- $\mathrm{HCl}(\mathrm{pH}$ 7.9), $10 \mathrm{mM} \mathrm{MgCl}_{2}, 50 \mathrm{mM} \mathrm{NaCl}, 1 \mathrm{mM}$ DTT, $20 \mu \mathrm{M}$ primer $\mathrm{D}$ (see Table 1 for sequence information), $0.2 \mathrm{mM}$ dNTPs, $10 \mathrm{U}$ of Klenow fragment $\left(3^{\prime} \rightarrow 5^{\prime} \mathrm{exo}^{-}\right)$(NEB) with initial denaturation at $95^{\circ} \mathrm{C}$ for $5 \mathrm{~min}$. followed by immediate cooling down at $4^{\circ} \mathrm{C}$, incubation at $37^{\circ} \mathrm{C}$ for 6 hours, and enzyme inactivation at $75^{\circ} \mathrm{C}$ for $20 \mathrm{~min}$. The synthesized probes were purified using QIAquick PCR purification kit (Qiagen), and the expected probe size was $\sim 200-650 \mathrm{bp}$.

2.4. Magnetic-Bead-Based Solid-Phase Preparation. The solid phase was prepared as described previously [31]. Briefly, $1 \mu \mathrm{m}$ size magnetic beads with amines $\left(\mathrm{NH}_{2}\right)$ were functionalized with a generation 5.5 phosphorous dendrimers, and a capture probe was immobilized at a concentration of $3,6,9$, and $12 \mathrm{ng} / \mu \mathrm{L}$ as previously described [31]. After, immobilization, the beads were stored at $4^{\circ} \mathrm{C}$ until used.

\subsection{Capture of rRNA Using a MICROBEnrich Kit (Two-Step} Method). The MICROBEnrich kit was used for the twostep method. The input RNA used for the experiments was either $500 \mathrm{ng}$ or $1000 \mathrm{ng}$ of total RNA (92.5\% rat thymus RNA/7.41\% E. coli RNA). The reactions were performed according to the manufacture's instruction. For the low target range (500 ng), the scaling of reagents was performed according to the manufacturer's indications.

2.6. Capture of rRNA Using Direct Capture (Single-Step Method). Capture reaction was performed as described previously [31] with the following modifications. The hybridization buffer was adjusted to $2.75 \mathrm{TMAC} / 0.01 \%$ SDS, and 1 unit of recombinant ribonuclease inhibitor (RNase OUT, Invitrogen Life Technologies) was added to each sample. The denaturing temperature was set at $72^{\circ} \mathrm{C}$, and the annealing temperature was varied from 40 to $60^{\circ} \mathrm{C}$. The denaturing 
TABLE 1: List of primers used in this study for the generation of capture probes and quantitative real-time reverse transcriptase PCR.

\begin{tabular}{|c|c|c|c|}
\hline Primer name & Sequence $\left(5^{\prime} \rightarrow 3^{\prime}\right)$ & Length (bp) & PCR condition \\
\hline $18 \mathrm{~S} R$ & GATCCTCTAGAACAGCAGCCG & 85 & \multirow{2}{*}{ See Section 2.2} \\
\hline $28 \mathrm{~S} R$ & ATCCTTCGATGTCGGCTCTTC & 100 & \\
\hline $\mathrm{D}^{*}$ & $\mathrm{NH}_{2}$-GTTTCCCAGTAGGTCTCNNNNNNNN & & See Section 2.3 \\
\hline T3 & $\mathrm{NH}_{2}$-GTTTCCCAGTAGGTCTCNNNNNNNN & & See Section 2.2 \\
\hline BR18S-F $F^{\#}$ & AGGAATTCCCAGTAAGTGCG & \multirow[b]{2}{*}{102} & 30 cycles of $94^{\circ} \mathrm{C}, 15^{\prime \prime}$; \\
\hline BR18S-R ${ }^{\#}$ & GCCTCACTAAACCATCCAA & & $60^{\circ} \mathrm{C}, 1^{\prime}$ \\
\hline 28SF4006 & CGCCGGTGAAATACCACTAC & \multirow[b]{2}{*}{200} & 35 cycles of $95^{\circ} \mathrm{C}, 15^{\prime \prime}$ \\
\hline 28SR4205 & CTGAGCTCGCCTTAGGACAC & & $55^{\circ} \mathrm{C}, 20^{\prime \prime} ; 72^{\circ} \mathrm{C}, 30^{\prime \prime}$ \\
\hline tdcA-F@ & CGGTGGTGGAAGTCTCATTT & \multirow[b]{2}{*}{173} & 35 cycles of $95^{\circ} \mathrm{C}, 10^{\prime \prime}$ \\
\hline tdcA-R $\mathrm{R}^{@}$ & ACCAATCGCAAAATCCAGTC & & $54^{\circ} \mathrm{C}, 20^{\prime \prime} ; 72^{\circ} \mathrm{C}, 20^{\prime \prime}$ \\
\hline
\end{tabular}

Note: * published primer from Wang et al. 2002 [32]. ${ }^{\#}$ Published primer pair from Grace et al. 2003 [33]. ${ }^{\circledR}$ Published primer pair from Lin et al. 2010 [34]. All other primer pairs are novel to this study. The length indicates amplicon size.

and annealing times were varied between 5 and 10 minutes and between 30 and 90 minutes, respectively, in order to optimize the capture conditions. The input RNA used was either $500 \mathrm{ng}$ or $1000 \mathrm{ng}$ of rat thymus RNA or total RNA ( $92.5 \%$ rat thymus RNA/7.41\% E. coli RNA).

2.7. Real-Time PCR. Quantitative real-time reverse transcriptase PCR (qRT-PCR) was performed using the MyiQ real-time PCR detection system with iScript one-step RTPCR kit with SYBR Green (Bio-Rad Laboratories, Inc.) according to the manufacturer's recommended protocol. Briefly, the reaction was carried out at $25 \mu \mathrm{L}$ volume with cDNA synthesis step at $50^{\circ} \mathrm{C}$ for $10 \mathrm{~min}$. and a denaturing step at $95^{\circ} \mathrm{C}$ for 5 minutes, followed by PCR cycling. The primers used and PCR cycling conditions are listed in Table 1. All qRT-PCR results were reported in terms of pg per microliter using an external standard curve with known concentration of total RNA.

\section{Results and Discussion}

In the work discussed here, we developed a single-step method to capture $18 \mathrm{~S}$ and $28 \mathrm{~S}$ rRNA using magnetic microbeads. The capture probes for $18 \mathrm{~S}$ and $28 \mathrm{~S}$ ribosomal RNA were covalently attached to magnetic microbeads through a phosphorous dendrimer to fabricate a solid phase, and the solid phase was characterized based on its capture efficiency and specificity at different probe concentrations. Rat thymus RNA (mammalian components) with E. coli RNA (bacterial target) was used as a model system to test the capture efficiency and monitor nonspecific absorption issue. After establishing the single-step method, the results were compared between the single-step and the commercially available two-step method.

3.1. Selection of Capture Probes. Random and specific capture probes were synthesized and immobilized on the magnetic microbeads to compare their capture efficiency. When using specific capture probes, magnetic microbeads were immobilized with either $18 \mathrm{~S}$ or $28 \mathrm{~S}$ probes or with a mixture of both, and subtraction experiments were performed separately. The results indicated that capture efficiency of magnetic beads are only at the $25-30 \%$ level regardless of the capture probes used (data not shown). A difficulty when utilizing specific capture probes is the difference in target length; it is expected that this parameter along with the base composition will strongly influence the capture efficiency. The targets are presented as whole strands of $\sim 1900$ and 5000 nucleotides (18S and 28S rRNA, resp.) that have to anneal to short capture probes in a specific region to ensure complementary base pair matching. This is indeed a restricted and complex scenario. Moreover, the probes are bound to a solid support, and it is well known that steric constraints become more significant under these conditions [30, 31].

In order to increase the degrees of freedom in the system and improve capture efficiency, we sought the use of random capture probes. Random rRNA capture probes are prepared from mammalian cDNA using a random primer which resulted in products that will span the whole $18 \mathrm{~S}$ and $28 \mathrm{~S}$ regions [33]. It is therefore expected that rather than constraining the capture to a specific short region of the target, they will represent a multitude of possible binding sites hence increasing the interaction probabilities. In addition, the length of these probes ranges from 200 to 650 nucleotides which is longer than specific capture probes and increases the chance to interact with targets. Our results indicated that random probes demonstrated significantly higher capture efficiencies (70-80\%) and more reproducible results. For this reason we pursued the remaining of our experiments using these probes.

3.2. Optimization of Capture Conditions. Our preliminary studies showed that denaturing at $72^{\circ} \mathrm{C}$ for 10 minutes followed by annealing at $50^{\circ} \mathrm{C}$ for 90 minutes produced satisfactory results using rat thymus RNA as target. While lower annealing temperatures produced a drastic decrease in the capture efficiency, variation in the denature time did not produce any significant effect (data not shown). These results provided a start point for further optimization. 
TABLE 2: Capture efficiency of $18 \mathrm{~S}$ and $28 \mathrm{~S}$ ribosomal RNA and recovery of $E$. coli RNA using a single-step capture protocol on a selective solid phase.

\begin{tabular}{lccc}
\hline & $\begin{array}{c}18 S \text { captured } \\
(\%)\end{array}$ & $\begin{array}{c}28 S \text { captured } \\
(\%)\end{array}$ & $\begin{array}{c}\text { E. coli recovered } \\
(\%)\end{array}$ \\
\hline $500 \mathrm{ng}$ & 87 & 51 & 4 \\
$1000 \mathrm{ng}$ & 51 & 32 & 46
\end{tabular}

Note: The input RNA tested was 500 and $1000 \mathrm{ng}$ of mixed mammalian (98\%) and E. coli (2\%) RNA. Denaturation was performed at $72^{\circ} \mathrm{C}$ for 10 minutes and annealing at $50^{\circ} \mathrm{C}$ for 90 minutes.

An important aspect of any direct capture method is to determine the selectivity and the capture efficiency within meaningful experimental ranges. It is well known that host ribonucleic acids can be present as much as more than 1000 fold excess with respect to the targets of interest. These large ratios are in fact one of the most difficult aspects of developing selective solid phases due to the likelihood of nonspecific hybridization (NSH) and nonspecific adsorption (NSA). In order to gain insight into the effect of these parameters, we challenged the solid phase with a matrix containing $92.5 \%$ of mammalian RNA and only $7.5 \%$ of E. coli total RNA and performed selective capture using the denature-and-capture conditions previously tested. We evaluated the capture efficiency of $18 \mathrm{~S}$ and $28 \mathrm{~S}$ ribosomal RNA and determined the percentage of E. coli recovered in the supernatant using real-time RT-PCR. These results showed a significant variation in the capture efficiency of $18 \mathrm{~S}$ and $28 \mathrm{~S}$ and recovery of $E$. coli among the different concentrations of input RNA (Table 2). Although a higher recovery of $E$. coli RNA is attained at higher concentration of input RNA, the variability is also significantly larger.

In order to address the capture efficiency and nonspecific interaction issues, different hybridization buffers were tested with tetramethylammonium chloride (TMA-Cl) showing the best results in terms of increase in capture efficiency and decrease in nonspecific interaction (data not shown). TMA-Cl is a chaotropic agent known to eliminate the dependence of base composition on the melting temperature of ribonucleic and deoxyribonucleic acids [35-38]. For RNA, TMAC-Cl-based buffer changes the stability of DNARNA duplexes. Yokogawa and coworkersv [39] found that tRNA was more likely to form hybrids with complementary oligonucleotides in a TMA-Cl buffer than in a NaCl-based buffer of the same ionic strength. Moreover, their results showed an increase in the capture efficiency of solid-supportbound oligonucleotides as the hybridization temperature was increased from $25^{\circ} \mathrm{C}$ to $65^{\circ} \mathrm{C}$ in a TMA-Cl-based buffer. The use of tetraalkylammonium salts also favors hybridization of mismatched bases which is a concern with regard to NSH; however, this effect can be ameliorated by annealing at higher temperatures $[39,40]$. Based on these facts, we decided to test whether an increase in the temperature and a reduction in the annealing time would favor the conditions to reduce NSH while maintaining the specific capture of rRNA. Annealing for 30 and 60 minutes was tested at $50^{\circ} \mathrm{C}$ and $60^{\circ} \mathrm{C}$; to facilitate the distribution of the target and potentially
TABLE 3: Capture and recovery efficiencies obtained by real-time RT-PCR. Capture was performed at $50^{\circ} \mathrm{C}$ using $500 \mathrm{ng}$ of input RNA (92.5\% mammalian and 7.5\% E. coli RNA).

\begin{tabular}{lll}
\hline Annealing time (min) & 30 & 60 \\
18 S captured (\%) & 31 & 20 \\
28 S captured (\%) & 41 & 71 \\
E. coli recovered $(\%)$ & 54 & 50 \\
\hline
\end{tabular}

enhance their diffusion to the surface-bound-probes, the beads were maintained under constant shaking. The results indicated that the most favorable condition to capture rRNA without nonspecific interaction occurred when $50^{\circ} \mathrm{C}$ was the annealing temperature (Table 3 ). The capture efficiencies dropped drastically above $50^{\circ} \mathrm{C}$ regardless of the annealing time or whether the capture was performed under intermittent or constant shaking (data not shown).

In comparison with the efficiencies obtained under intermittent shaking for a longer period of time (Table 2, $500 \mathrm{ng}$ ), there is a significant improvement in the recovery of E. coli. The variable efficiency obtained for $18 \mathrm{~S}$ and $28 \mathrm{~S}$ might be due to the difference in their size or a different stabilizing effect of the TMA-Cl on the probe-target duplex.

In addition to hybridization buffer, variation in stringency of the posthybridization wash has been demonstrated to reduce NSB (nonspecific binding) and NSH (nonspecific hybridization) $[38,41]$. We tested whether an increase in the posthybridization wash temperature would enhance the recovery of $E$. coli by incubating the beads in the wash solution for five minutes at either 37 or $50^{\circ} \mathrm{C}$. We found that for the SSC/SDS buffer used, the optimal temperature was $37^{\circ} \mathrm{C}$ and higher temperatures produced a detrimental effect (data not shown). These results demonstrated that the annealing temperature and time and the presumed maintenance of a homogeneous distribution of the targets by means of shaking influence the performance of the capture probes; moreover, different effects are observed in the efficiency of the $28 \mathrm{~S}$ and the $18 \mathrm{~S}$ probes. So far, the information available with regard to the effect of TMA$\mathrm{Cl}$ on RNA is limited to short capture probes and known targets, and therefore it is difficult to pinpoint the specific mechanism involved in the observed results. It is possible that the enhancement on the recovery of the E. coli RNA might be a combined effect of the TMA-Cl, which is known to positively influence the hybridization of exact matching sequences [37], and a better, more uniform access of the target to the probes, by means of the continuous shaking. For short RNA targets and probes, increased hybridization temperature produces an enhancement in the hybridization efficiency [39]; however, the opposite effect was observed in this study. It is not clear why increasing hybridization temperature causes a decrease in hybridization efficiency in this case. It is probably due to the fact that the rRNA targets are much longer in this work and potentially exhibit different characteristics than short RNAs used by Yokogawa et al. [39]. The cause of the difference in efficiency observed between the $18 \mathrm{~S}$ and the $28 \mathrm{~S}$ probes may be the base composition and duplex stability of the $18 \mathrm{~S}$ and $28 \mathrm{~S}$ targets. 
TABLE 4: Comparison of subtraction efficiencies between the single-step and the two-step method using a commercially available enrichment kit (MICROBEnrich, Ambion).

\begin{tabular}{lcccccc}
\hline & \multicolumn{3}{c}{ 500 ng input } & & 1000 ng input \\
\hline & $\begin{array}{c}\text { Captured 18S } \\
(\%)\end{array}$ & $\begin{array}{c}\text { Captured 28S } \\
(\%)\end{array}$ & $\begin{array}{c}\text { Recovered E. coli } \\
(\%)\end{array}$ & $\begin{array}{c}\text { Captured 18S } \\
(\%)\end{array}$ & $\begin{array}{c}\text { Captured 28S } \\
(\%)\end{array}$ & $\begin{array}{c}\text { Recovered E. coli } \\
(\%)\end{array}$ \\
\hline Commercial method & 29 & 40 & 63 & 30 & 50 & 100 \\
Proposed method & 31 & 41 & 54 & 60 & 92 & 36 \\
\hline
\end{tabular}

3.3. Effect of Probe Density on the Capture Efficiency. We previously demonstrated that the probe density has a significant effect on the capture of genomic NAs [31]. The experiments performed so far were done using a probe concentration of $3 \mathrm{ng} / \mu \mathrm{L}$ based on our previous study with human genomic DNA. In order to investigate how this variable would affect the capture of RNA, we performed a series of experiments utilizing $3,6,9$, and $12 \mathrm{ng} / \mu \mathrm{L}$ as initial probe concentration. We also increased the amount of input RNA to $1 \mu \mathrm{g}$ to determine whether the conditions previously established could be used in matrices with large ratio of background to target RNA. In contrast to DNA subtraction, the difference of the probe density did not produce significant difference in capture efficiency of $18 \mathrm{~S}$ and $28 \mathrm{~S}$ rRNA.

It was also interesting to note that the recovery of $E$. coli was reduced as the input RNA concentration increased. The maximum recovery of $E$. coli is $36 \%$ when using $1 \mu \mathrm{g}$ of input RNA which is lower than the recovery obtained with lower input RNA (Table 3 ). The low recovery is presumably due to the fact that the increase in the input RNA increased the effects of NSH and NSB. The interaction of nucleic acids at the solid/liquid interface is complex and depends not only on the characteristics of the target but also on the surface properties of the solid phase such as hydrophilicity and the presence of blocking agents $[42,43]$. In the method used here bovine serum albumin (BSA) was used to minimize nonspecific interactions, and the use of a final concentration of $0.125 \mu \mathrm{g} / \mu \mathrm{L}$ has been proven satisfactory for DNA and RNA targets up to $500 \mathrm{ng}$ [31]. In order to enhance the results obtained at higher input RNA, further fine tuning of the hybridization buffer, such as increased BSA concentration, and posthybridization wash is warranted to improve the recovery rate of E. coli. The use of TMA-Cl posthybridization wash buffers at temperatures of or about $50^{\circ} \mathrm{C}$ has been demonstrated to benefit NSH and NSB [38]. Future experiments will incorporate these two parameters for further optimizations of the protocol.

3.4. Comparison with a Commercially Available Two-Step Method. In order to determine how the proposed method performed in comparison with other methods, we performed subtraction experiments using 500 and $1000 \mathrm{ng}$ of total RNA using a commercially available kit for bacterial RNA enrichment (MICROBEnrich, Ambion). The results indicated that the subtraction efficiency of the one-step method developed in this study is comparable to the commercially available kit (Table 4) with the exception of the E. coli recovery rate.
It is worth emphasizing that the minimum amount of total RNA recommended by the commercially available kit is $1000 \mathrm{ng}$; however, the indications for reagent scaling provided by the manufacturer appeared suitable for the lower input range as well. When comparing the results obtained with the commercially available kit, it is important to keep in mind that solution-and solid-phase hybridizations represent very different scenarios with regard to the constraints imposed on the target capture. Thermodynamic and kinetic parameters vary significantly among these two making the solid-phase hybridization more complex and therefore more challenging to attain [42]. Despite the complexity of solidphase hybridization, our results showed the potential of the proposed method for single-step capture of RNA and enrichment of bacterial targets. As mentioned in the previous section, at the higher RNA input ranges, adjustments in the BSA concentration and posthybridization wash conditions might enhance the recovery of $E$. coli and provide a better assessment for the $18 \mathrm{~S}$ and $28 \mathrm{~S}$ specific capture.

\section{Conclusion}

We have developed and demonstrated a method to capture mammalian ribosomal RNA in a single step using a magnetic microbead-based solid phase. Our results indicated that specific capture of $18 \mathrm{~S}$ and $28 \mathrm{~S}$ rRNA can be attained in matrices containing 500 to $1000 \mathrm{ng}$ of total RNA. The capture efficiency with the proposed one-step method depends significantly on the hybridization conditions such as buffer composition, annealing temperature, and time. While the use of specific capture probes did not show satisfactory results, random ones significantly enhanced the performance, presumably by increasing the probability of interaction with the targets. The use of TMA-Cl in the buffer is likely to be enhancing the specific capture by stabilizing the DNA-RNA duplex. TMA-Cl has also been demonstrated to influence the charge profile of RNA, hence its secondary structure. This might also be contributing to the stabilizing effect [35]. Comparison between the developed method and a commercially available kit for enrichment showed comparable performance of the two methods except the recovery rate of E. coli. Further improvements of the protocol such as adjustment of BSA concentration with the amount of target and the use of a TMA-Cl posthybridization buffer are expected to enhance the performance of the solid phase. The method developed here has the advantages of being a flexible platform that enables the use of any capture probe and less number of manual steps which reduces the risk of 
contamination and loss of template. The successful proofof-concept experiments demonstrated here show that this approach is potentially very useful for various applications.

\section{Acknowledgments}

This study was sponsored by the Defense Threat Reduction Agency. The authors thank Dr. Jinny Liu and Ms. Lisa Shriver-Lake for critically reviewing the manuscript. They also thank Ms. Nina Long for her assistance in generating the magnetic-microbead-based solid phase. The views expressed here are those of the authors and none are to be construed as those of the Defense Threat Reduction Agency, the U. S. Navy, the U. S. Department of Defense, or the U. S. Government at large.

\section{References}

[1] I. G. Wilson, "Inhibition and facilitation of nucleic acid amplification," Applied and Environmental Microbiology, vol. 63, no. 10, pp. 3741-3751, 1997.

[2] S. Berensmeier, "Magnetic particles for the separation and purification of nucleic acids," Applied Microbiology and Biotechnology, vol. 73, no. 3, pp. 495-504, 2006.

[3] S. Fleige and M. W. Pfaffl, "RNA integrity and the effect on the real-time qRT-PCR performance," Molecular Aspects of Medicine, vol. 27, no. 2-3, pp. 126-139, 2006.

[4] R. P. Perry, J. LaTorre, D. E. Kelley, and J. R. Greenberg, "On the lability of poly(A) sequences during extraction of messenger RNA from polyribosomes," Biochimica et Biophysica Acta, vol. 262, no. 2, pp. 220-226, 1972.

[5] P. Muir, F. Nicholson, M. Jhetam, S. Neogi, and J. Banatvala, "Rapid diagnosis of enterovirus infection by magnetic bead extraction and polymerase chain reaction detection of enterovirus RNA in clinical specimens," Journal of Clinical Microbiology, vol. 31, no. 1, pp. 31-38, 1993.

[6] L. J. van Doorn, A. van Belkum, G. Maertens, W. Quint, T. Kos, and H. Schellekens, "Hepatitis $\mathrm{C}$ virus antibody detection by a line immunoassay and (near) full length genomic RNA detection by a new RNA-capture polymerase chain reaction," Journal of Medical Virology, vol. 38, no. 4, pp. 298-304, 1992.

[7] F. Beaulieux, D. M. See, I. Leparc-Goffart, M. Aymard, and B. Lina, "Use of magnetic beads versus guanidium thiocyanatephenol-chloroform RNA extraction followed by polymerase chain reaction for the rapid, sensitive detection of enterovirus RNA," Research in Virology, vol. 148, no. 1, pp. 11-15, 1997.

[8] C. Albretsen, K. H. Kalland, B. I. Haukanes, L. S. Havarstein, and K. Kleppe, "Applications of magnetic beads with covalently attached oligonucleotides in hybridization: isolation and detection of specific measles virus mRNA from a crude cell lysate," Analytical Biochemistry, vol. 189, no. 1, pp. 40-50, 1990.

[9] J. van Ness, S. Kalbfleisch, C. R. Petrie, M. W. Reed, J. C. Tabone, and N. M. J. Vermeulen, "A versatile solid support system for oligodeoxynucleotide probe-based hybridization assays," Nucleic Acids Research, vol. 19, no. 12, pp. 3345-3350, 1991.

[10] G. Amagliani, E. Omiccioli, A. del Campo, I. J. Bruce, G. Brandi, and M. Magnani, "Development of a magnetic capture hybridization-PCR assay for Listeria monocytogenes direct detection in milk samples," Journal of Applied Microbiology, vol. 100, no. 2, pp. 375-383, 2006.
[11] B. Spottke, J. Gross, H. J. Galla, and F. Hillenkamp, "Reverse Sanger sequencing of RNA by MALDI-TOF mass spectrometry after solid phase purification," Nucleic Acids Research, vol. 32, no. 12, p. e97, 2004.

[12] L. J. van Doorn, B. Kleter, J. Voermans et al., "Rapid detection of hepatitis C virus RNA by direct capture from blood," Journal of Medical Virology, vol. 42, no. 1, pp. 22-28, 1994.

[13] T. C. H. Hsuih, Y. N. Park, C. Zaretsky et al., "Novel, ligationdependent PCR assay for detection of hepatitis C virus in serum," Journal of Clinical Microbiology, vol. 34, no. 3, pp. 501507, 1996.

[14] D. P. Chandler, J. R. Stults, S. Cebula et al., "Affinity purification of DNA and RNA from environmental samples with peptide nucleic acid clamps," Applied and Environmental Microbiology, vol. 66, no. 8, pp. 3438-3445, 2000.

[15] P. M. Regan and A. B. Margolin, "Development of a nucleic acid capture probe with reverse transcriptase-polymerase chain reaction to detect poliovirus in groundwater," Journal of Virological Methods, vol. 64, no. 1, pp. 65-72, 1997.

[16] H. J. Bach, A. Hartmann, J. T. Trevors, and J. C. Munch, "Magnetic capture-hybridization method for purification and probing of mRNA for neutral protease of Bacillus cereus," Journal of Microbiological Methods, vol. 37, no. 2, pp. 187-192, 1999.

[17] H. Miyachi, A. Masukawa, T. Ohshima, T. Hirose, C. Impraim, and Y. Ando, "Automated specific capture of hepatitis C virus RNA with probes and paramagnetic particle separation," Journal of Clinical Microbiology, vol. 38, no. 1, pp. 18-21, 2000.

[18] R. M. Satokari, K. Kataja, and H. Söderlund, "Multiplexed quantification of bacterial $16 \mathrm{~S}$ rRNA by solution hybridization with oligonucleotide probes and affinity capture," Microbial Ecology, vol. 50, no. 1, pp. 120-127, 2005.

[19] B. W. Bogan, B. Schoenike, R. T. Lamar, and D. Cullen, "Manganese peroxidase mRNA and enzyme activity levels during bioremediation of polycyclic aromatic hydrocarboncontaminated soil with phanerochaete chrysosporium," Applied and Environmental Microbiology, vol. 62, no. 7, pp. 2381-2386, 1996.

[20] L. J. Chandler, C. D. Blair, and B. J. Beaty, "Detection of dengue-2 viral RNA by reversible target capture hybridization," Journal of Clinical Microbiology, vol. 31, no. 10, pp. 2641-2647, 1993.

[21] F. Di Cello, Y. Xie, M. Paul-Satyaseela, and K. S. Kim, "Approaches to bacterial RNA isolation and purification for microarray analysis of Escherichia coli $\mathrm{K} 1$ interaction with human brain microvascular endothelial cells," Journal of Clinical Microbiology, vol. 43, no. 8, pp. 4197-4199, 2005.

[22] J. Thompson, R. Solomon, M. Pellegrino et al., "A noise-free molecular hybridization procedure for measuring RNA in cell lysates," Analytical Biochemistry, vol. 181, no. 2, pp. 371-378, 1989.

[23] L. Törmäkangas, L. Erkkilä, T. Korhonen et al., "Effects of repeated Chlamydia pneumoniae inoculations on aortic lipid accumulation and inflammatory response in C57BL/6J mice," Infection and Immunity, vol. 73, no. 10, pp. 6458-6466, 2005.

[24] K. Y. Salim, D. G. Cvitkovitch, P. Chang et al., "Identification of group A Streptococcus antigenic determinants upregulated in vivo," Infection and Immunity, vol. 73, no. 9, pp. 6026-6038, 2005.

[25] C. J. Orihuela, J. N. Radin, J. E. Sublett, G. Gao, D. Kaushal, and E. I. Tuomanen, "Microarray analysis of pneumococcal gene expression during invasive disease," Infection and Immunity, vol. 72, no. 10, pp. 5582-5596, 2005. 
[26] A. de Saizieu, U. Certa, J. Warrington, C. Gray, W. Keck, and J. Mous, "Bacterial transcript imaging by hybridization of total RNA to oligonucleotide arrays," Nature Biotechnology, vol. 16, no. 1, pp. 45-48, 1998.

[27] J. E. Graham and J. E. Clark-Curtiss, "Identification of Mycobacterium tuberculosis RNAs synthesized in response to phagocytosis by human macrophages by selective capture of transcribed sequences (SCOTS)," Proceedings of the National Academy of Sciences of the United States of America, vol. 96, no. 20, pp. 11554-11559, 1999.

[28] G. Plum and J. E. Clark-Curtiss, "Induction of Mycobacterium avium gene expression following phagocytosis by human macrophages," Infection and Immunity, vol. 62, no. 2, pp. 476483, 1994.

[29] C. Su and L. M. Sordillo, "A simple method to enrich mRNA from total prokaryotic RNA," Molecular Biotechnology, vol. 10, no. 1, pp. 83-85, 1998.

[30] M. J. Archer, B. Lin, Z. Wang, and D. A. Stenger, "Magnetic bead-based solid phase for selective extraction of genomic DNA," Analytical Biochemistry, vol. 355, no. 2, pp. 285-297, 2006.

[31] M. J. Archer, N. Long, and B. Lin, "Effect of probe characteristics on the subtractive hybridization efficiency of human genomic DNA," BMC Research Notes, vol. 3, article 109, 2010.

[32] D. Wang, L. Coscoy, M. Zylberberg et al., "Microarray-based detection and genotyping of viral pathogens," Proceedings of the National Academy of Sciences of the United States of America, vol. 99, no. 24, pp. 15687-15692, 2002.

[33] M. B. Grace, C. B. McLeland, S. J. Gagliardi, J. M. Smith, W. E. Jackson III, and W. F. Blakely, "Development and assessment of a quantitative reverse transcription-PCR assay for simultaneous measurement of four amplicons," Clinical Chemistry, vol. 49, no. 9, pp. 1467-1475, 2003.

[34] B. Lin, B. J. Johnson, R. A. Rubin, A. P. Malanoski, and F. S. Ligler, "Iron chelation by cranberry juice and its impact on Escherichia coli growth," Biofactors, vol. 37, no. 2, pp. 121-130, 2011.

[35] T. Golas, M. Miller, and D. Shugar, "The effects of tetraalkylammonium salts on helix-coil transition parameters in natural and synthetic ribo- and deoxyribo-polynucleotides," Chemico-Biological Interactions, vol. 30, no. 2, pp. 209-222, 1980.

[36] J. G. Wetmur, W. T. Ruyechan, and R. J. Douthart, “Denaturation and renaturation of Penicillium chrysogenum mycophage double-stranded ribonucleic acid in tetraalkylammonium salt solutions," Biochemistry, vol. 20, no. 11, pp. 2999-3002, 1981.

[37] W. I. Wood, J. Gitschier, L. A. Lasky, and R. M. Lawn, "Base composition-independent hybridization in tetramethylammonium chloride: a method for oligonucleotide screening of highly complex gene libraries," Proceedings of the National Academy of Sciences of the United States of America, vol. 82, no. 6, pp. 1585-1588, 1985.

[38] M. L. Collins, C. Bloomquist, M. Lombardo, and J. Eldredge, "Methods for improving the sensitivity of hybridization assays," U.S. Patent 5,702,896, 1997.

[39] T. Yokogawa, Y. Kitamura, D. Nakamura, S. Ohno, and K. Nishikawa, "Optimization of the hybridization-based method for purification of thermostable tRNAs in the presence of tetraalkylammonium salts," Nucleic Acids Research, vol. 38, no. 6, p. e89, 2010.

[40] K. A. Jacobs, R. Rudersdorf, S. D. Neill, J. P. Dougherty, E. L. Brown, and E. F. Fritsch, "The thermal stability of oligonucleotide duplexes is sequence independent in tetraalkylammonium salt solutions: application to identifying recombinant
DNA clones," Nucleic Acids Research, vol. 16, no. 10, pp. 46374650, 1988.

[41] B. J. Conner, A. A. Reyes, C. Morin, K. Itakura, R. L. Teplitz, and R. B. Wallace, "Detection of sickle cell $\beta$ S-globin allele by hybridization with synthetic oligonucleotides," Proceedings of the National Academy of Sciences of the United States of America, vol. 80, no. 1, pp. 278-282, 1983.

[42] R. Levicky and A. Horgan, "Physicochemical perspectives on DNA microarray and biosensor technologies," Trends in Biotechnology, vol. 23, no. 3, pp. 143-148, 2005.

[43] V. Chan, S. E. McKenzie, S. Surrey, P. Fortina, and D. J. Graves, "Effect of hydrophobicity and electrostatics on adsorption and surface diffusion of DNA oligonucleotides at liquid/solid interfaces," Journal of Colloid and Interface Science, vol. 203, no. 1, pp. 197-207, 1998. 

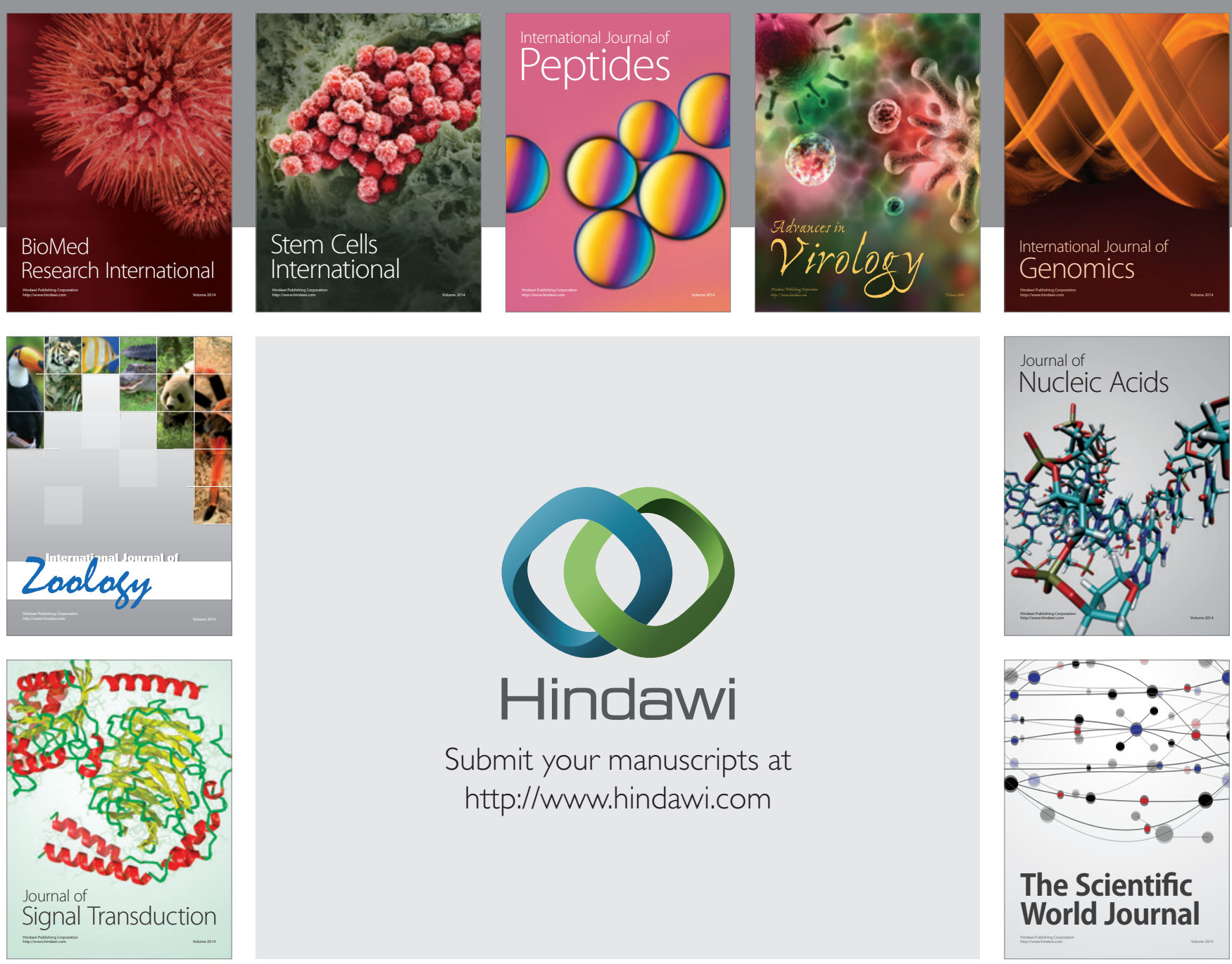

Submit your manuscripts at

http://www.hindawi.com
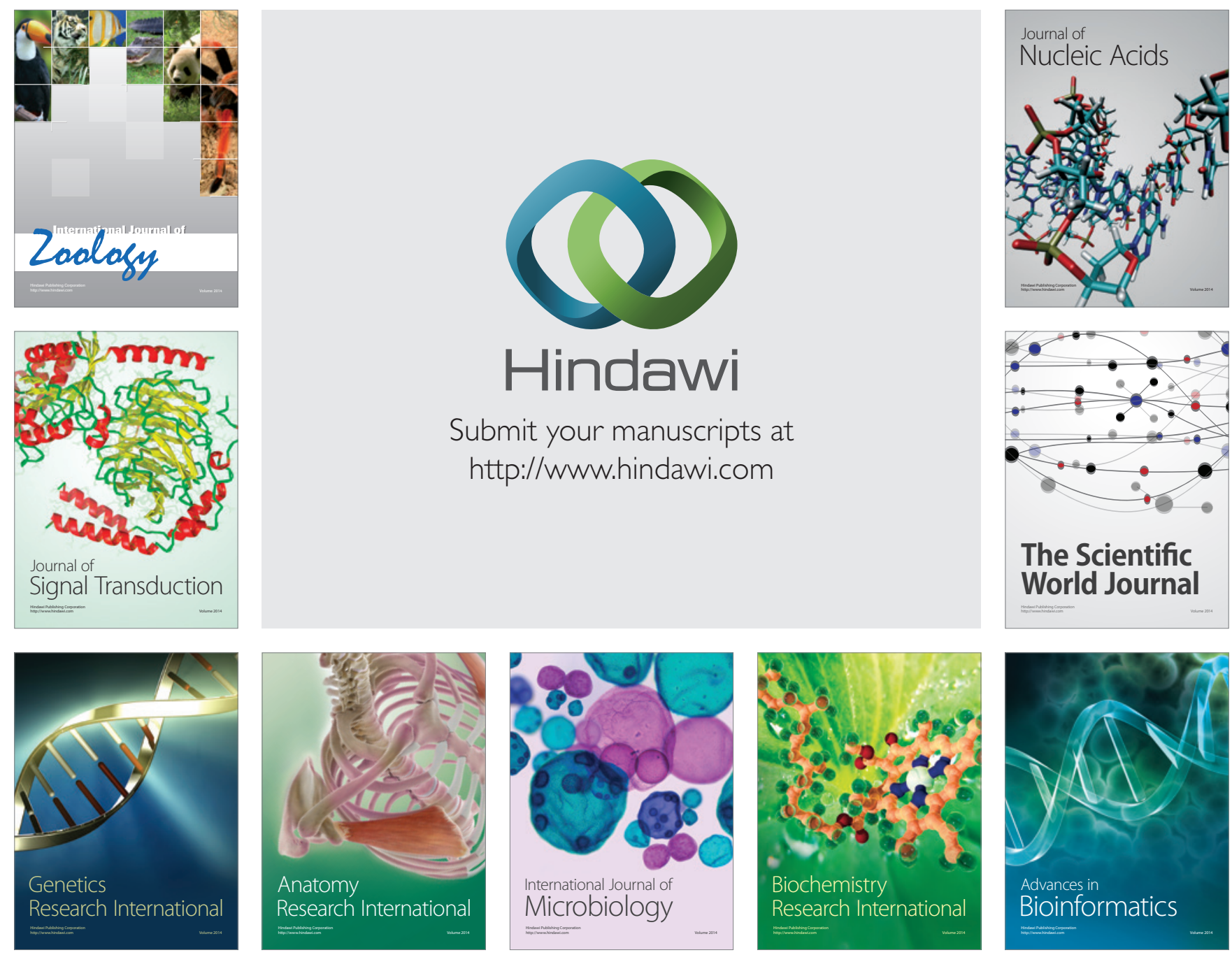

The Scientific World Journal
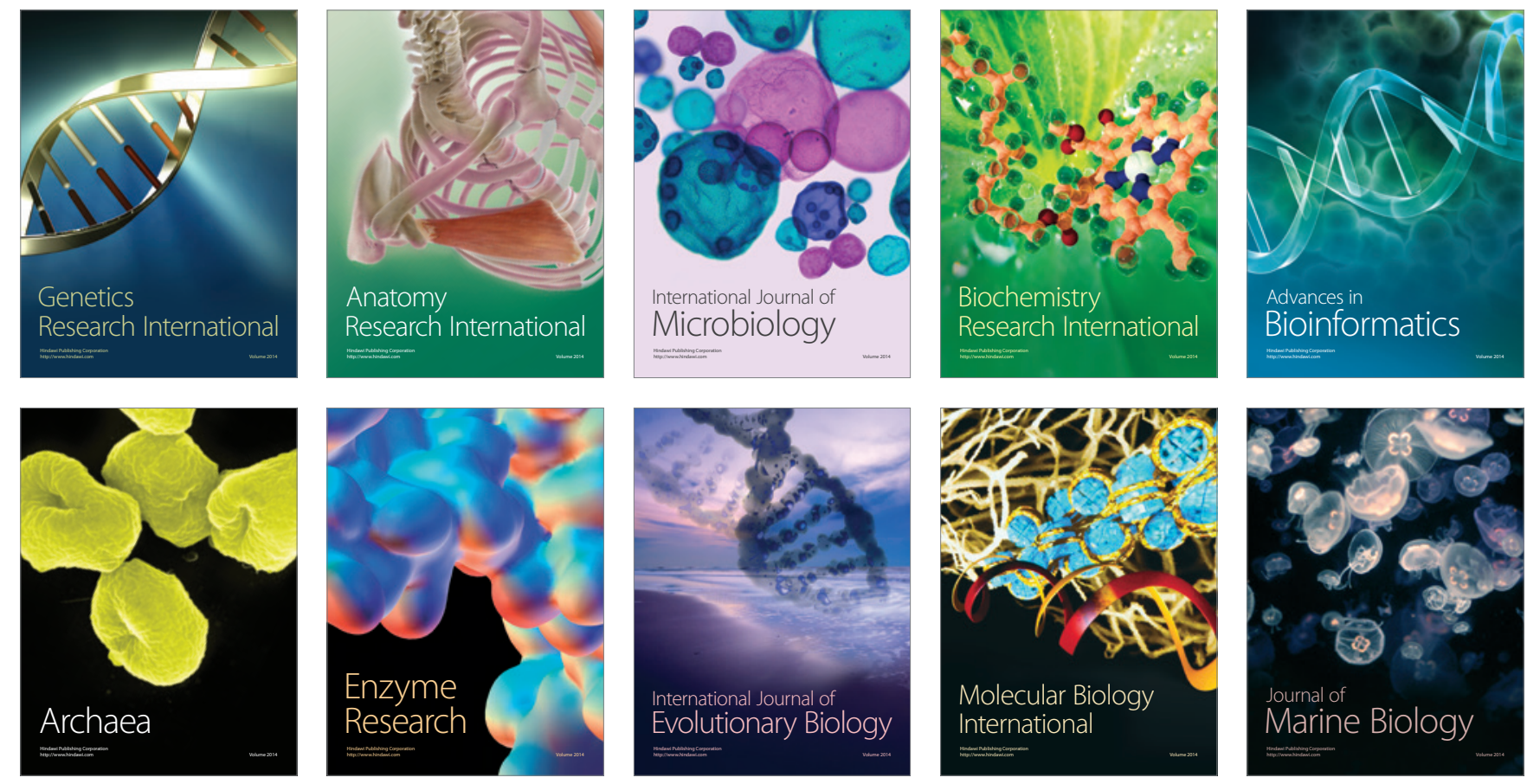